\title{
The Effect of Application of Cold Natural Smoke on the Ripening of Cheddar Cheese
}

\author{
Shakeel-Ur-Rehman, ${ }^{\star}$ N. Y. Farkye, ${ }^{\star}$ and M. A. Drake† \\ ${ }^{*}$ Dairy Products Technology Center, California Polytechnic State University, \\ San Luis Obispo, CA 93407 \\ †Southeast Dairy Foods Research Center, North Carolina State University, Raleigh, NC 27695
}

\begin{abstract}
The present study was undertaken to study the effects of application of natural wood smoke on ripening of Cheddar cheese, and to determine the effects of smoking before or after ripening on cheese quality. A 20-kg block of Cheddar cheese obtained immediately after pressing was divided into six $\sim 3-\mathrm{kg}$ blocks and ripened at $8^{\circ} \mathrm{C}$ for up to $270 \mathrm{~d}$. One 3 -kg block was taken after $1 \mathrm{~d}, 1$, 3,6 , or $9 \mathrm{mo}$ and smoked for $20 \mathrm{~min}$, then returned to the ripening room for further ripening. Cheeses were sampled at intervals for lactobacilli counts, moisture, $\mathrm{pH}$, and proteolysis. Sensory analysis was conducted on 6 and 9-mo-old cheeses by a trained sensory panel $(\mathrm{n}=7)$. Results show that application of natural wood smoke did not significantly affect cheese $\mathrm{pH}$ or primary proteolysis during ripening. However, secondary proteolysis as assessed by the concentrations of free amino acids was generally higher in smoked cheeses than in control cheeses after 6 mo of ripening. Cheese smoked after 6 mo of ripening had better smoked flavor than that smoked after 9 mo of ripening. Cheese smoked after 3 mo of age and further ripened for 6 mo had the highest smoked flavor intensity. It is concluded that it is best to smoke cheese after ripening for at least 3 mo. (Key words: smoking, Cheddar cheese, proteolysis)
\end{abstract}

\section{INTRODUCTION}

Smoking of foods is one of the oldest methods of food preservation but, presently, foods are smoked for sensory quality rather than for preservative effect. In general, smoking infuses the high-protein food with aromatic components, which lend flavor and color to the food and also play bacteriostatic and anitioxidant roles (Bratzler et al., 1969; Poutler, 1988; Horner, 1992). There are reports that phenolic compounds found in smoke inhibit growth of molds on smoked Cheddar cheese (Wendorff et al., 1993).

Received September 27, 2002.

Accepted January 6, 2003.

Corresponding author: N. Y. Farkye; email: nfarkye@calpoly.edu.
Although Cheddar remains a commodity cheese, diversifying Cheddar cheese flavor will help boost sales. Smoking of cheese is one of the ways to diversify flavors. The most common varieties of cheese that are smoked are Seretpanir (Iran), Caramakase (Germany), Bandal (India), and Provolone (Italy). In a study at Michigan State University in the 1960 s, it was found that smoked cheeses sold at 10 cents per pound more than similar nonsmoked cheeses and increased sales by $45 \%$ (Kosikowski and Mistry, 1997).

Riha and Wendorff (1993) studied the color of retail smoked Cheddar and Swiss cheeses by sensory and objective methods and reported that surface color is one of the major attributes affecting the consumer acceptance of smoked cheeses. Traditionally, cheese is smoked by application of natural smoke; however, some manufacturers prefer liquid smoke. Liquid smoke is generally used as a preservative and aromatizer for meat and fish (Hattula et al., 2001). Riha et al (1992) reported that smoked Cheddar or Swiss available in the Wisconsin market had been smoked with natural vaporous smoke or liquid smoke flavorings. Mcllveen and Vallely (1996) developed a smoked process cheese by incorporating Cheddar cheese and a liquid smoke flavor. In a consumer study, Hendrick et al (1960) reported that cheeses flavored with hardwood smoke were preferred over that flavored with liquid smoke concentrate.

The objectives of the study were to determine the effect of natural smoking on ripening and flavor development of Cheddar cheese. The other objective was to find whether it was better to smoke the cheese and then ripen or to ripen before application of natural smoke.

\section{MATERIALS AND METHODS}

\section{Cheese Manufacture}

Cheddar cheese was manufactured by a standard protocol (Kosikowski and Mistry, 1997) on three separate occasions (three trials). A 20-kg block of Cheddar cheese on each occasion was divided into six portions of $\sim 3 \mathrm{~kg}$ $(27 \times 16 \times 8 \mathrm{~cm})$ each and were vacuum packaged in Cryovac (Sealed Air Corporation, Duncan, SC) bags. 
Table 1. Time protocol for smoking and sampling of smoked cheeses.

\begin{tabular}{|c|c|}
\hline Cheese & Treatment \\
\hline Block 1 (A) & $\begin{array}{l}\text { (Control) Cheeses were ripened for } 9 \text { mo without smoking. } \\
\text { Samples were taken after } 1,3,6 \text { and } 9 \text { mo for microbiological } \\
\text { analysis and proteolysis. }\end{array}$ \\
\hline Block 2 (B) & $\begin{array}{l}\text { Cheeses were smoked } 1 \mathrm{~d} \text { postmanufacture, and then ripened for } 9 \\
\text { mo. Samples were taken from the block after } 3,6 \text {, and } 9 \text { mo of } \\
\text { ripening for analysis. }\end{array}$ \\
\hline Block 3 (C) & $\begin{array}{l}\text { Cheeses were smoked after } 1 \text { mo of ripening, and then ripened for } \\
\text { an additional } 8 \text { mo. Samples were taken from the block after } 6 \text { and } \\
9 \text { mo of ripening for analysis. }\end{array}$ \\
\hline Block 4 (D) & $\begin{array}{l}\text { Cheeses were smoked after } 3 \text { mo of ripening and then ripened for } \\
\text { additional } 6 \text { mo. Samples were taken from the block after } 6 \text { and } 9 \\
\text { mo of ripening for analysis. }\end{array}$ \\
\hline Block $5(\mathrm{E})$ & $\begin{array}{l}\text { Cheeses were smoked after } 6 \text { mo of ripening and then ripened for an } \\
\text { additional } 3 \text { mo. Samples were taken after } 9 \text { mo of ripening. }\end{array}$ \\
\hline Block $6(\mathrm{~F})$ & $\begin{array}{l}\text { Cheeses were smoked after } 9 \text { mo of ripening. Samples were taken } \\
\text { immediately after smoking for analysis. }\end{array}$ \\
\hline
\end{tabular}

The portions, randomly labeled A through $\mathrm{F}$, were placed in a ripening room at $8^{\circ} \mathrm{C}$. After $1 \mathrm{~d}, 1,3,6$, and 9 mo of ripening one block was taken in consecutive order, and subjected to wood smoke for $20 \mathrm{~min}$, and then returned to the ripening room. The cheeses were vacuum packaged immediately after smoking in Crovac bags. The experimental design for smoking of cheese and sampling of the smoked cheeses is given in Table 1. Samples for analysis were stored at $-20^{\circ} \mathrm{C}$ till analyzed. The cheeses were placed on stainless steel wire racks and smoked in a programmed Joe-Smoker model BIG JOE 140 (PK Manufacturing Inc., Pittsburg, KS). The Joe-Smoker operates on a cycle consisting of preheat $\left(48.9^{\circ} \mathrm{C}\right)$, smoking-temperature $\left(46^{\circ} \mathrm{C}\right)$, smoking-time (20 min) and hold temperature $\left(46^{\circ} \mathrm{C}\right)$. The preheat temperature is the maximum temperature achieved to generate smoke; the smoking time is that cheese remains in contact with smoke inside the chamber. The distance from the source of smoke to the cheese was $\sim 90 \mathrm{~cm}$. The smoke time was selected based on preliminary experiments. The smoke source was hickory woodchips (Fire Spice, Weber-Stephen Products, Palatine, IL) soaked in water for $30 \mathrm{~min}$ prior to smoldering at $48.9^{\circ} \mathrm{C}$. When the chamber of the smoker was filled with smoke, the cheeses were placed on a rack in the smoker. Then the door of the smoker was closed and the cheeses were held inside the chamber for $20 \mathrm{~min}$. The temperature in the center of the cheese block reached $18^{\circ} \mathrm{C}$ while the surface temperature $2 \mathrm{~cm}$ beneath the block surface was $31^{\circ} \mathrm{C}$ during smoking.

\section{Compositional Analysis}

Fat in cheese was analyzed by the Babcock method (Marshall, 1992). Moisture was determined by the microwave oven method (CEM AVC 80 microwave oven,
CEM Corporation, Mattehew, NC) (Marshall, 1992). Protein (total $\mathrm{N} \times 6.38$ ) was determined by the Kjeldahl method (AOAC, 1990) salt by a titrimetric method using a chloride analyzer 926 (Corning, Medfield, MA). Cheese $\mathrm{pH}$ was determined using a glass electrode on a slurry prepared by thoroughly blending $10 \mathrm{~g}$ of grated cheese with $10 \mathrm{ml}$ deionized water using a mortar and pestle. Cheeses were analyzed 7-d postmanufacture for compositional attributes. Moisture and $\mathrm{pH}$ in the cheeses were also determined in 1-d-old cheeses and during the ripening.

\section{Microbiological Analysis}

Cheese samples ( $10 \mathrm{~g}$ ) were mixed with $90 \mathrm{ml}$ of warm $\left(40^{\circ} \mathrm{C}\right)$ sterile $2 \% \mathrm{Na}$ citrate at and homogenized in a Stomacher for $3 \mathrm{~min}$. Decimal dilutions of the homogenate were plated on Rogosa agar (Difco Laboratories, Detriot, MI) and incubated anaerobically for $5 \mathrm{~d}$ at $31^{\circ} \mathrm{C}$ for nonstarter lactic acid bacteria (NSLAB). The NSLAB are the only bacteria that grow during the ripening of Cheddar cheese (Peterson and Marshall, 1990).

\section{Measurement of Proteolysis}

Cheese samples (200 g) were taken after $1 \mathrm{~d}, 1,3,6$, and 9 mo of ripening and frozen at $-20^{\circ} \mathrm{C}$ until analyzed for proteolysis. Urea-PAGE of cheeses was performed as described by Farkye (1995). Water-soluble fractions of the cheeses were prepared according to the method of Kuchroo and Fox (1982) and N content determined by the Kjeldahl method (AOAC, 1990). Urea-PAGE and levels of water-soluble $\mathrm{N}$ are used to assess primary proteolysis in Cheddar cheese. Total free amino acids (used to assess secondary proteolysis) were determined by the method of Folkerstma and Fox (1992). 
Table 2. Effect of smoking on the moisture content of Cheddar cheese during ripening for 9 mo.

\begin{tabular}{|c|c|c|c|c|c|c|}
\hline \multirow[b]{2}{*}{ Block/ Treatment } & \multicolumn{5}{|c|}{ Mean $\%$ moisture in cheese during ripening } & \multirow{2}{*}{$\begin{array}{l}\text { Overall } \\
\text { mean }^{2}\end{array}$} \\
\hline & $1 \mathrm{~d}$ & $1 \mathrm{mo}$ & $3 \mathrm{mo}$ & $6 \mathrm{mo}$ & $9 \mathrm{mo}$ & \\
\hline \multirow[t]{2}{*}{ A (no smoking) } & $\begin{array}{c}35.74 \\
( \pm 0.34)^{1}\end{array}$ & $\begin{array}{c}35.50 \\
( \pm 0.45)\end{array}$ & $\begin{array}{c}35.50 \\
( \pm 0.45)\end{array}$ & $\begin{array}{c}36.33 \\
( \pm 0.85)\end{array}$ & $\begin{array}{c}35.55 \\
( \pm 0.18)\end{array}$ & $\begin{array}{c}35.72^{\mathrm{d}} \\
( \pm 0.45)\end{array}$ \\
\hline & & & 35.74 & 36.41 & 35.92 & $36.02^{\text {cd }}$ \\
\hline \multirow[t]{2}{*}{ B (smoked after $1 \mathrm{~d}$ ) } & & & $( \pm 0.34)$ & $( \pm 0.67)$ & $( \pm 0.27)$ & $( \pm 0.42)$ \\
\hline & & & & 36.57 & 36.81 & $36.69^{\mathrm{ab}}$ \\
\hline \multirow[t]{2}{*}{$\mathrm{C}$ (smoked after $1 \mathrm{mo})$} & & & & $( \pm 0.87)$ & $( \pm 0.43)$ & $( \pm 0.65)$ \\
\hline & & & & $\begin{array}{c}36.53 \\
(+1.37)\end{array}$ & $\begin{array}{c}36.99 \\
(+0.51)\end{array}$ & $\begin{array}{c}36.76^{a b} \\
( \pm 0.94)\end{array}$ \\
\hline D (smoked after $3 \mathrm{mo}$ ) & & & & & $\begin{array}{l}\text { (I0.01) } \\
37.06\end{array}$ & $37.06^{\mathrm{a}}$ \\
\hline \multirow[t]{2}{*}{$\mathrm{E}$ (smoked after 6 mo) } & & & & & $( \pm 0.78)$ & $( \pm 0.78)$ \\
\hline & & & & & $\begin{array}{c}36.78 \\
( \pm 1.29)\end{array}$ & $\begin{array}{c}36.78^{\mathrm{ab}} \\
( \pm 1.29)\end{array}$ \\
\hline & & & & & (II.ZJ) & \\
\hline
\end{tabular}

\section{Sensory Analysis}

Flavor attributes of 6 and 9-mo-old cheeses were evaluated by a trained 7-member sensory panel using 17 terms for Cheddar flavor previously identified by Drake et al. (2001) plus two additional terms specific for smoked cheeses (smokey and skunky). Definitions and references for the Cheddar flavor sensory descriptors have been previously published (Drake et al., 2001). Smokey flavor was defined as the "aromatic reminiscent of burning wood" with liquid smoke used as a reference for the descriptor. The term skunky was defined as the "sour sulfur aromatic reminiscent of skunk odor."

The panel consisted of 5 females and 2 males, each with more than $80 \mathrm{~h}$ of training on descriptive sensory analysis of cheese. Panelists evaluated and scored descriptors using a 10-point universal intensity scale consistent with the Spectrum descriptive analysis tech- nique (Meilgaard et al., 1999; Drake and Civille, 2003). Prior to sensory analysis, the outer edges $(1 \mathrm{~cm})$ of each block were carefully trimmed and discarded to minimize variability. Cheeses were prepared by slicing into $4 \times 2 \times 2 \mathrm{~cm}$ cubes using a wire slicer within $2 \mathrm{~h}$ of evaluation. Cheeses were placed into 113.5-g soufflé cups with lids and tempered to $12^{\circ} \mathrm{C}$ prior to evaluation. Cheeses were evaluated in a balanced block design using three digit codes under white light. The order of presentation of cheese samples was randomized among panelists. Panelists had access to water and unsalted crackers throughout evaluation. Panelists evaluated four cheeses per session and each cheese was evaluated in duplicate.

\section{Statistical Analysis}

Cheesemaking was replicated three times. Each analysis (composition, microbiology, water-soluble $\mathrm{N}$,

Table 3. Effect of smoking on the $\mathrm{pH}$ of Cheddar cheese during ripening for 9 mo.

\begin{tabular}{|c|c|c|c|c|c|}
\hline \multirow[b]{2}{*}{ Block/Treatment } & \multicolumn{5}{|c|}{$\mathrm{Mean}^{1} \mathrm{pH}$ of cheeses during ripening ${ }^{2}$} \\
\hline & $1 \mathrm{~d}$ & $1 \mathrm{mo}$ & $3 \mathrm{mo}$ & $6 \mathrm{mo}$ & $9 \mathrm{mo}$ \\
\hline A (no smoking) & $\begin{array}{c}5.17 \\
( \pm 0.01)^{3}\end{array}$ & $\begin{array}{c}5.15 \\
( \pm 0.03)\end{array}$ & $\begin{array}{c}5.15 \\
( \pm 0.03) \\
5.17\end{array}$ & $\begin{array}{c}5.37 \\
( \pm 0.07) \\
5.34\end{array}$ & $\begin{array}{c}5.36 \\
( \pm 0.06) \\
5.44\end{array}$ \\
\hline B (smoked after $1 \mathrm{~d}$ ) & & & $( \pm 0.01)$ & $\begin{array}{c}( \pm 0.12) \\
5.31\end{array}$ & $\begin{array}{c}( \pm 0.12) \\
5.44\end{array}$ \\
\hline C (smoked after $1 \mathrm{mo}$ ) & & & & $\begin{array}{c}( \pm 0.07) \\
5.39\end{array}$ & $\begin{array}{c}( \pm 0.04) \\
5.40\end{array}$ \\
\hline D (smoked after 3 mo) & & & & $( \pm 0.04)$ & $\begin{array}{c}( \pm 0.09) \\
5.38\end{array}$ \\
\hline E (smoked after 6 mo) & & & & & $\begin{array}{c}( \pm 0.08) \\
5.37\end{array}$ \\
\hline F (smoked after 9 mo) & & & & & $( \pm 0.08)$ \\
\hline
\end{tabular}

${ }^{1}$ Means of three trials analyzed in triplicate.

${ }^{2} P$-values: treatment $=0.0629$; time $=0.0001$.

${ }^{3}$ Figures in parenthesis are standard deviations. 
Table 4. Effect of smoking of Cheddar cheese on the growth of nonstarter lactic acid bacteria ${ }^{1}$ during the ripening for $9 \mathrm{mo}$.

\begin{tabular}{lllllll}
\hline & \multicolumn{5}{c}{ NSLAB count $(\mathrm{cfu} / \mathrm{g})^{1}$} & \multicolumn{1}{l}{ Overall $^{1}$} \\
\cline { 2 - 6 } Block/ Treatment & $1 \mathrm{~d}$ & $1 \mathrm{mo}$ & $3 \mathrm{mo}$ & $6 \mathrm{mo}$ & $9 \mathrm{mo}$ & mean $^{2}$ \\
\hline A (no smoking) & $<10$ & $<10$ & $6.77 \times 10^{3}$ & $1.36 \times 10^{5}$ & $8.13 \times 10^{6}$ & $2.75 \times 10^{6 \mathrm{c}}$ \\
B (smoked after 1 d) & & & $9.83 \times 10^{4}$ & $1.62 \times 10^{6}$ & $7.13 \times 10^{6}$ & $2.95 \times 10^{6 \mathrm{c}}$ \\
C (smoked after 1 mo) & & & & $5.88 \times 10^{6}$ & $2.45 \times 10^{6}$ & $4.17 \times 10^{6 \mathrm{c}}$ \\
D (smoked after 3 mo) & & & & $2.06 \times 10^{6}$ & $4.21 \times 10^{6}$ & $3.13 \times 10^{6 \mathrm{c}}$ \\
E (smoked after 6 mo) & & & & & $1.06 \times 10^{7}$ & $1.06 \times 10^{7 \mathrm{a}}$ \\
F (smoked after 9 mo) & & & & $5.29 \times 10^{6}$ & $5.29 \times 10^{6 \mathrm{~b}}$ \\
\hline
\end{tabular}

${ }^{\mathrm{a}, \mathrm{b}, \mathrm{c}}$ Means in a column with different superscript letters differ significantly $(P<0.05)$.

${ }^{1}$ Mean of three trials analyzed in duplicate.

${ }^{2} P$ values: treatment $=0.0182 ;$ time $=0.0053$.

free amino acids, sensory analysis) were conducted in duplicate within each cheesemaking trial. Data were analyzed by the general linear model analysis of variance (PROC GLM) with least square means using the SAS statistical software (Version 8.0; SAS, Cary, NC). Main effects (treatment, time) and interactions (treatment $\times$ time) were evaluated. Significance was established at $P<0.05$.

\section{RESULTS AND DISCUSSION}

\section{Composition}

The mean percentages of moisture, fat, protein and salt-in-moisture in the 7-d-old cheeses were $35.50 \pm$ $0.50,33.33 \pm 1.04,24.98 \pm 0.21$ and $3.48 \pm 0.58$, respectively and these values are within normal values for
Cheddar. Application of smoke to Cheddar cheese increased the percentage of moisture in a narrow range from 35.50 to 37.06 (Table 2) during ripening. In general, cheeses smoked after ripening for 3 mo or longer had increased moisture levels. The increases in the moisture in the cheese due to cold smoking were probably due to high humidity in the smoking chamber caused by smoldering of wet woodchips. This was confirmed by placing $2 \mathrm{~g}$ anhydrous $\mathrm{Na}_{2} \mathrm{SO}_{4}$ in the smoker under similar conditions for smoking cheese. Moisture gain in $\mathrm{Na}_{2} \mathrm{SO}_{4}$ was $1.3 \%$. Moisture content of cheeses did not change with ripening time $(P>0.05)$ and was not expected to since cheeses were vacuum-sealed during ripening. The $\mathrm{pH}$ of cheeses increased with ripening time from 5.17 in 1-d-old cheeses to 5.36 to 5.40 in 9 mo-old cheeses (Table 3). Application of smoke to cheese did not significantly $(P>0.05)$ affect cheese $\mathrm{pH}$, but $\mathrm{pH}$ increased significantly $(P<0.05)$ with ripening time.

Table 5. Influence of smoking of Cheddar cheese on the concentration ${ }^{1}$ of total free amino acids (mg Leu / $\mathrm{g}$ cheese) during ripening for $9 \mathrm{mo}$.

\begin{tabular}{lccccc}
\hline & \multicolumn{4}{c}{ Concentration of total free amino acids (mg Leu/g cheese) } \\
\cline { 2 - 6 } Block/Treatment & $1 \mathrm{~d}$ & $1 \mathrm{mo}$ & $3 \mathrm{mo}$ & $6 \mathrm{mo}$ & $9 \mathrm{mo}$ \\
\hline & $1.33^{\mathrm{i}}$ & $3.20^{\mathrm{h}}$ & $4.88^{\mathrm{g}}$ & $7.80^{\mathrm{e}}$ & $14.92^{\mathrm{b}}$ \\
A (no smoking) & $( \pm 0.48)^{3}$ & $( \pm 0.57)$ & $( \pm 0.08)$ & $( \pm 0.90)$ & $( \pm 0.16)$ \\
& & & $6.83^{\mathrm{f}}$ & $11.91^{\mathrm{c}}$ & $14.79^{\mathrm{b}}$ \\
B (smoked after 1 d) & & $( \pm 0.49)$ & $( \pm 0.61)$ & $( \pm 0.87)$ \\
C (smoked after 1 mo) & & & $8.30^{\mathrm{e}}$ & $14.73^{\mathrm{b}}$ \\
& & & $( \pm 0.09)$ & $( \pm 1.3)$ \\
D (smoked after 3 mo) & & & $\left( \pm 0.45^{\mathrm{d}}\right.$ & $14.80^{\mathrm{b}}$ \\
E (smoked after 6 mo) & & & & $( \pm 0.02)$ \\
& & & & $\left( \pm 0.26^{\mathrm{a}}\right.$ \\
F (smoked after 9 mo) & & & & $15.28^{\mathrm{ab}}$ \\
\end{tabular}

\footnotetext{
${ }^{\mathrm{a}, \mathrm{b}}$ Means with different superscript letters differ significantly $(P<0.05)$.

${ }^{1}$ Means of three trials analyzed in triplicate.

${ }^{2} P$ values: Treatment $=0.0004 ;$ time $=0.0001 ;$ treatment $\times$ time $=0.0002$. Since a significant interaction existed, the treatment by time combinations are compared.

${ }^{3}$ Figures in parenthesis are standard deviations.
} 


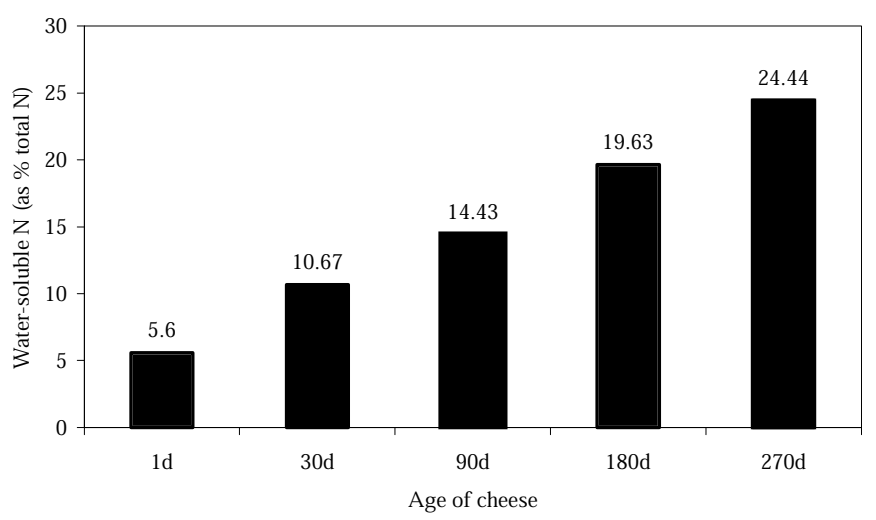

Figure 1. Influence of smoking of Cheddar cheese on the watersoluble N during ripening (treatment, $P=0.1732$; time, $P=0.001$. Since there was not a treatment effect, only the main effect of time is reported).

\section{Lactobacilli Growth}

No growth of NSLAB was detected in any cheese up to $1 \mathrm{mo}$ of ripening, however at the end of $6 \mathrm{mo}$, the smoked cheeses had NSLAB numbers higher by 1 log cycle than control cheese (Table 4). After 9 mo of ripening, the control and most of the smoked cheeses had similar numbers of NSLAB $\left(10^{6} / \mathrm{g}\right)$ except that 9-moold cheeses which were smoked at 6 mo of age had $10^{7}$ cfu NSLAB/g cheese. The interaction effect of smoking and the age of cheese at smoking had significant effects $(P<0.01)$ on the growth of NSLAB. The increased moisture due to cold smoking did not affect the final numbers of NSLAB as most of the smoked cheeses had similar numbers of NSLAB as that of control after 9 mo of ripening. Lane et al. (1997) reported that NSLAB populations in Cheddar cheeses were independent of moisture contents within normal ranges in Cheddar cheese. Also, application of cold smoke to MRS broth did not affect the growth of Lactobacillus casei ATCC 334 (Shakeel-Ur-Rehman and Farkye, unpublished data).

\section{Proteolysis}

Levels of water-soluble nitrogen (WSN) in the cheeses are given in Figure 1. The smoking treatment had no

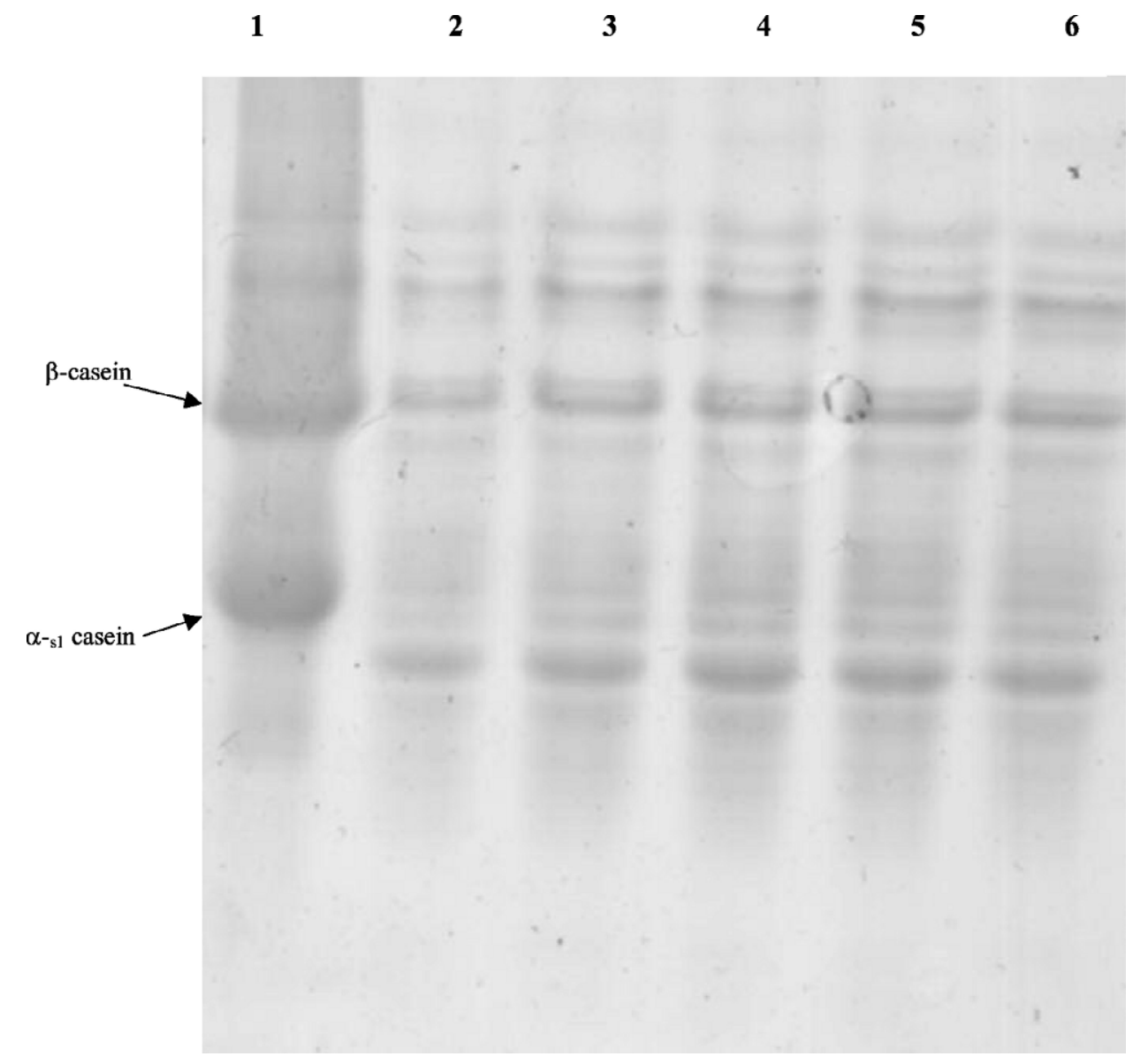

Figure 2. Urea-polyacrylamide gel electrophoretograms of 6-mo-old cheeses. Lane 1 is control sodium caseinate, lane 2 is nonsmoked cheese, lanes $3,4,5$, and 6 are cheeses that were smoked after $1 \mathrm{~d}, 1,3$, and 6 mo. 


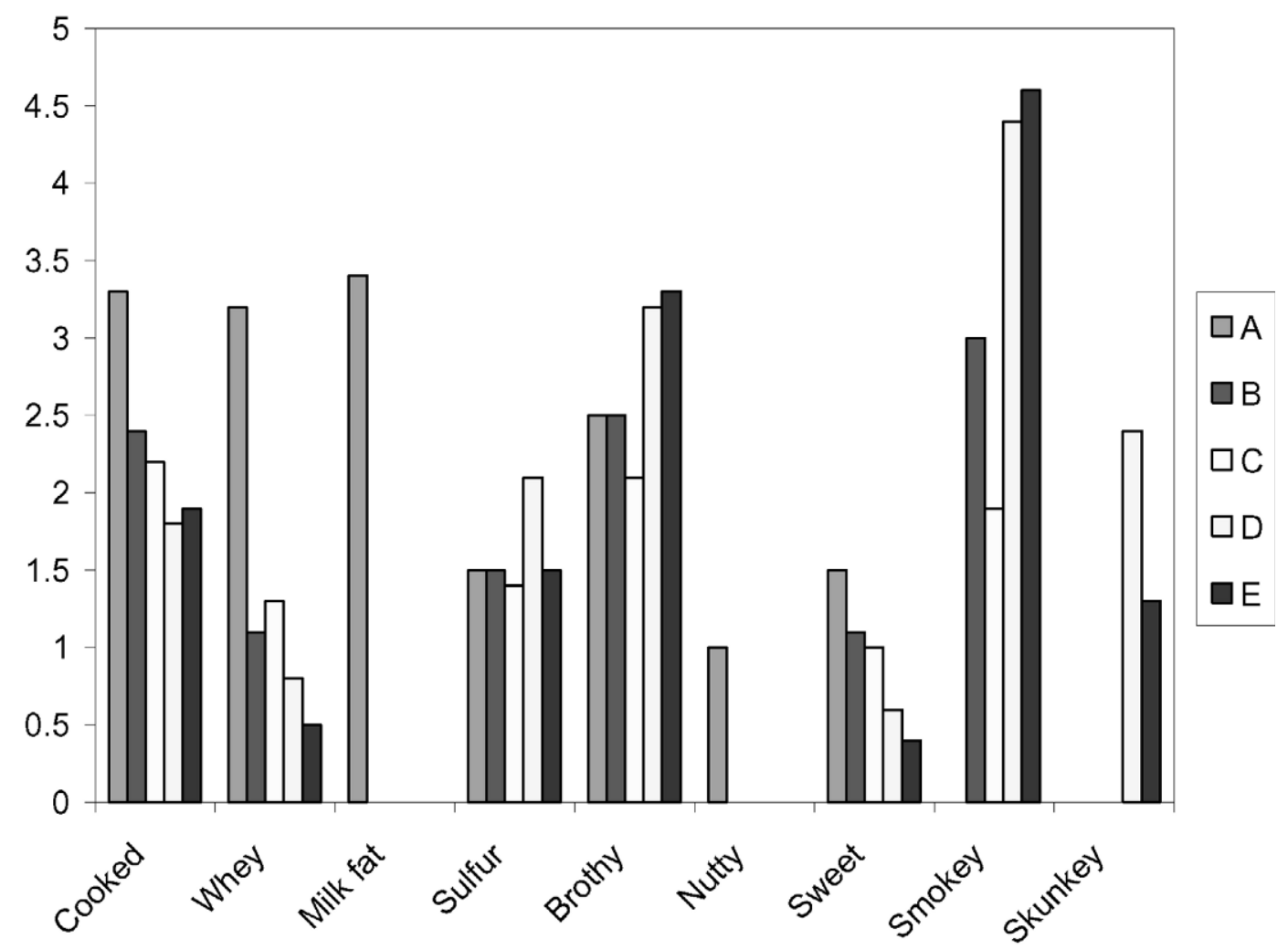

Figure 3. Descriptive sensory profiles of control and smoked Cheddar cheeses after 6 mo of ripening. A is unsmoked cheese, B, C, D, E and $\mathrm{F}$ cheeses were smoked after $1 \mathrm{~d}, 1 \mathrm{mo}, 3 \mathrm{mo}, 6 \mathrm{mo}$ and $9 \mathrm{mo}$. Flavor intensities were scored using a 10-point scale anchored on the left with "not" and on the right with "very."

significant effect $(P>0.05)$ on the levels of WSN suggesting that smoking of cheese did not affect primary proteolysis. The time of ripening caused significant $(P$ $<0.01$ ) changes in the level of WSN, which ranged from $5.6 \%$ in 1-d-old cheese to $24.4 \%$ in 9 -mo-old cheese. Urea-PAGE of the cheeses showed no differences between the smoked and nonsmoked cheeses after 6 mo of ripening (Fig 2). This suggests that subjecting cheese to smoke did not affect activities of indigenous milk proteinase, plasmin, and residual chymosin, which are responsible for the production of most of the WSN and the level of proteolysis detectable by urea-PAGE of cheeses.

Subjecting cheese to wood smoke significantly $(P<$ 0.01 ) influenced the concentration of free amino acids (FAA) (Table 5). The 3 or 6 -mo-old cheeses that were smoked $1 \mathrm{~d}$ postmanufacture had the highest concentration of FAA compared to other cheeses of similar age. Generally, the concentration of FAA in smoked cheeses was higher than nonsmoked cheeses. The reason for this cannot be explained. The accumulations of amino acids during the ripening of Cheddar cheese depend on the formation of amino acid and their conversion to flavor compounds.

\section{Sensory Evaluation}

Sensory analysis results of the cheeses are given in Figures 3 and 4 . Flavor scores of only those attributes that show significant differences $(P<0.05)$ are given. For cheeses aged 6 mo, the control cheeses exhibited higher intensities of "cooked," "whey," "milkfat," "sweet" and "nutty" flavors (Figure 2) than the smoked cheeses. Similarly, control cheeses aged for 9 mo also exhibited significantly higher intensities of "cooked," "whey," "milkfat," "sulfur" and "nutty" flavors (Figure 3) than smoked cheeses. Previous research has shown that as Cheddar cheeses age, intensities of cooked, whey, and milkfat flavors decrease (Drake et al., 2001). In addition, smoking contributes strong flavors that likely diminish perception of the intensities of these flavors in smoked cheeses.

Two flavors were identified by sensory panelists as being specific to smoked cheeses: smokey and skunky flavors. Intensities of these two distinct flavors varied with the time of the application of the smoke treatment and the age of the cheese. Six-mo-old cheeses that were smoked at 6 or 3 mo of age had the highest intensities of "smoked" flavor, but the 6-mo-old cheese smoked at 


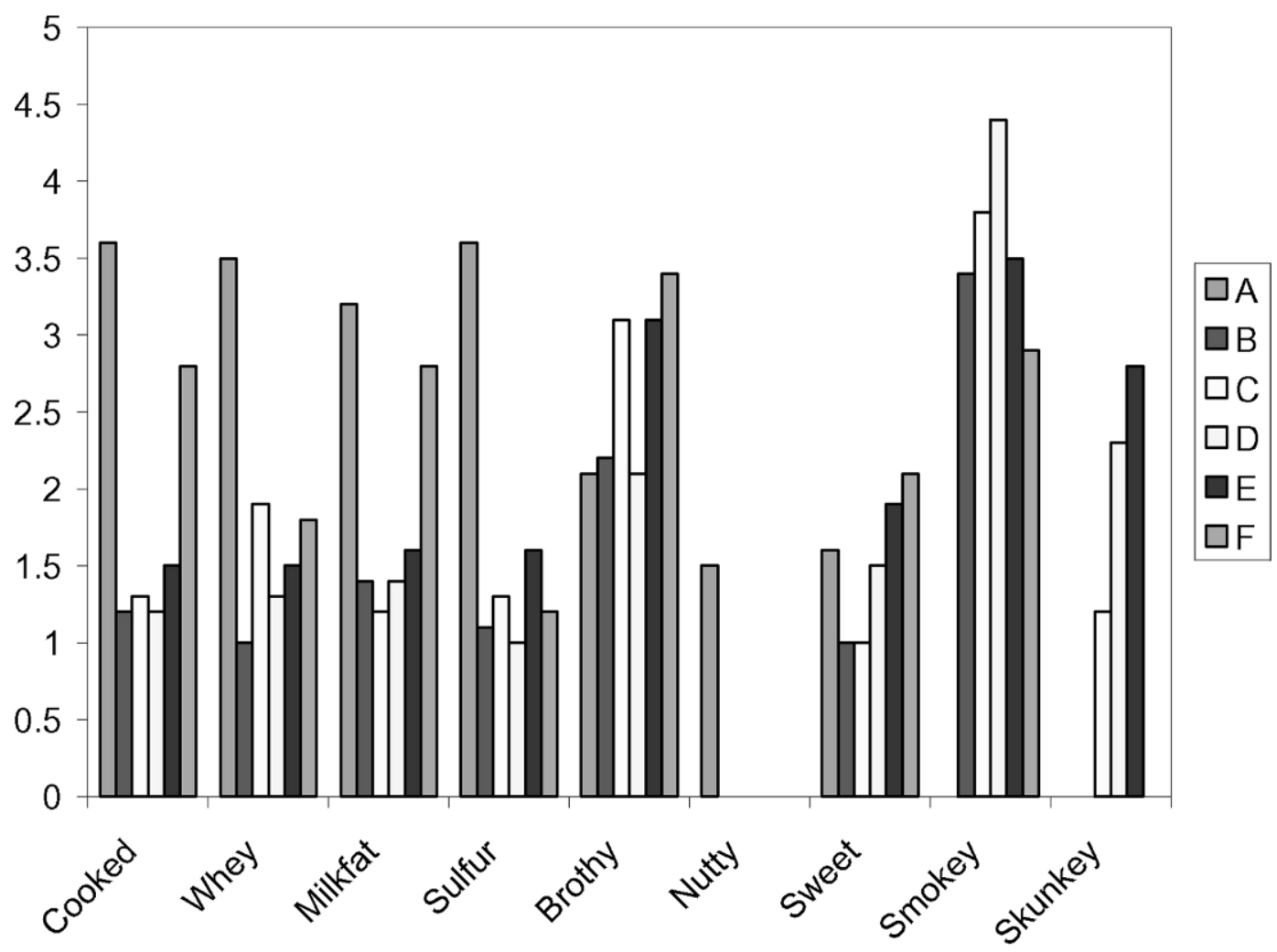

Figure 4. Descriptive sensory profiles of control and smoked Cheddar cheeses after 9 mo of ripening. A is unsmoked cheese, B, C, D, E and $\mathrm{F}$ cheeses were smoked after $1 \mathrm{~d}, 1,3,6$, and 9 mo. Flavor intensities were scored using a 10-point scale anchored on the left with "not" and on the right with "very."

3 mo of age had a very high skunky flavor. Nine-moold cheeses smoked after 3 mo had the highest intensity $(P<0.05)$ of smoked flavor and a lower intensity of skunky flavor compared to cheeses of similar age that were smoked at 6 or 9 mo $(P<0.05)$, suggesting that the intensity of skunky flavor substantially decreased in the ripening time between 6 and 9 mo. Future research should address consumer acceptability to determine which smoke flavor profiles are most desirable.

\section{CONCLUSIONS}

This study shows that application of cold smoke did not significantly affect primary proteolysis during the ripening of Cheddar cheese. According to the trained panel, smoking cheese after it had been ripened for 3 or 6 mo gives the most desirable smoked flavor in Cheddar cheese.

\section{ACKNOWLEDGMENTS}

This study was supported by a grant from the California State University Agriculture Research Initiative. Assistance of Boorus Yim in the analyses of cheese is appreciated.

\section{REFERENCES}

Association of Official Analytical Chemists. 1990. Official Methods of Analysis. Vol I. 15th ed. AOAC, Arlington, VA.

Bratzler, L. T., M. E. Spooner, J. B. Weathersspoon, and J. A. Maxey. 1969. Smoke flavor as related to phenols carbonyl and acid content of Bologna. J. Food Sci. 34:146-148.

Drake, M. A., S. C. McIngvale, K. R. Cadwallader, and G. V. Civille. 2001. Development of a descriptive sensory language for Cheddar cheese. J. Food. Sci. 66:1422-1427.

Drake, M. A., and G. V. Civille. 2003. Flavor Lexicons. Compr. Rev. Food Sci. 2:33-40

Farkye, N. Y. 1995. Contribution of milk-clotting enzymes and plasmin to cheese ripening. Pages 195-200 in Chemistry of Structure/ Function Relationship in cheese. E. L. Malin and M. H. Tunick, eds. New York: Plenum Press.

Folkertsma, B., and P. F. Fox. 1992. Use of the Cd-ninhydrin reagent to assess proteolysis in cheese during ripening. J. Dairy Res. $59: 217-224$

Hatulla, T., and T. Luoma. 2001. Use of liquid smoke flavourings as an alternative to traditional flue gas smoking of rainbow trout Fillets (Oncorhynchus mykiss). Lebensem-Wiss-U Technol. 34:521-525.

Hendrick, T. T., L. T. Bratzler, and G. M. Trout. 1960. Smoked flavored Cheddar cheese. Quarterly Bulletin, Michigan Agricultural Experimental Station. 42:4.

Horner, B. 1992. Fish smoking: Ancient and modern. Food Sci. Tech. Today 6:166-171.

Kosikowski, F. V., and V. V. Mistry. 1997. Cheese and Fermented Milk Foods, vol 1. Origins and principles. WestPort, CT. F. V. Kosikowski, LLC. 
Kuchroo C. N., and P. F. Fox. 1982. Soluble nitrogen in Cheddar cheese: comparision of extraction procedures. Milchwissenchaft. 37:331-335.

Lane, C. N., P. F. Fox, E. M. Walsh, B. Folkertsma, and P. L. H. McSweeney. 1997. Effect of composition and environmental factors on the growth of indigenous nonstarter lactic acid bacteria in Cheddar cheese. Lait. 77:561-573.

Marshall, T. R., ed. 1992. Standard Methods for the Examination of Dairy Products. 15th ed. Am. Publ. Health Assoc., Inc., Washington DC.

Mcllveen, H., and C. Vallely. 1996. The development and acceptability of a smoked processed cheese. Br. Food J. 98:17-23.

Meilgaard, M. M., G. V. Civille, and B. T. Carr, 1999. Descriptive analysis techniques. Pages 187-199 in Sensory Evaluation Techniques. CRC Press, New York, NY.
Peterson, S. D., and R. T. Marshall. 1990. Nonstarter lactic acid bacteria in Cheddar cheese: A review. J. Dairy Sci. 73:1395-1410.

Poulter, R. G. 1988. Processing and storage of traditional dried and smoked fish products. Pages 85-90 in Fish smoking and drying, the effect of smoking on nutritional properties of fish. J. R. Burt, Ed. Elsevier Appl. Sci., London.

Riha, W. E., and W. L. Wendorff. 1993. Evaluation of color in smoked cheese by sensory and objective methods. J. Dairy Sci. 76:1491-1497.

Riha, W. E., W. L. Wendorff, and S. Rank. 1992. Benzo(a) pyrene content of smoked and smoked flavored cheese products sold in Wisconsin. Food Prot. 55:636-638.

Wendorff, W. L., W. E. Riha, and E. Muehlenkamp. 1993. Growth of molds on cheese treated with heat or liquid smoke. J. Food Prot. 56:936-966. 